\title{
Crohn's Disease and Membranous Glomerulonephritis Case Report
}

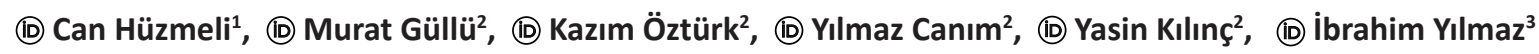

${ }^{1}$ Assoc Prof., Hatay State Hospital, Nephrology Clinic, Hatay, Turkey.

${ }^{2}$ M.D. Spec., Hatay State Hospital, Internal Medicine Clinic, Hatay, Turkey.

${ }^{3}$ M.D Spec., Hatay State Hospital, Gastroenterology Clinic, Hatay, Turkey.

Öz

Crohn Hastalı̆̆ı ve Membranöz Glomerulonefrit Olgu Sunumu

Inflamatuar barsak hastalıkları (IBD) Crohn hastalığı ve Ülseratif kolit olmak üzere birbirinden faklı olan iki tip kronik noninfeksiyöz gastrointestinal inflamatuar hastalıktır. IBH ekstraintestinal tutulumları arasında renal tutulum olmaktadır. IBH renal tutulumlar, glomerulonefrit, tübulointerstisyel nefrit, nefrolitiyazis ve renal amiloidozis șeklinde olmaktadır. Bu makalede nefrotik proteinüri ile bașvuran 79 yașında erkek hastada renal biyopsi ile membranöz glomerulonefrit tanısı kondu. Ayrıca yapılan kolonoskopi ile alınan barsak biyopsisinde Crohn hastalığı tanısı konan hastayı literatür eşliğinde tartışmayı amaçladık.

Anahtar Kelimeler: Crohn Hastalı̆̆ı, Proteinüri, İnflamatuar Barsak Hastalıkları

\section{Abstract}

\section{Crohn's Disease and Membranous Glomerulonephritis Case Report}

Inflammatory bowel diseases (IBD) are two different types of chronic noninfectious gastrointestinal inflammatory diseases, namely Crohn's disease and Ulcerative colitis. Renal involvement exists among the extraintestinal involvements of IBD. IBD renal involvements are in the form of glomerulonephritis, tubulointerstitial nephritis, nephrolithiasis, and renal amyloidosis. In this article, a 79-yearold male patient who presented with nephrotic proteinuria was diagnosed with membranous glomerulonephritis by renal biopsy. In addition, this article aims to discuss the patient who was diagnosed with Crohn's disease in intestinal biopsy taken with colonoscopy while also referring to relative literature.

Keywords: Crohn's Disease, Proteinuria, Inflammatory Bowel Disease

Nasıl Atıf Yapmalı: Hüzmeli C, Güllü M, Öztürk K, Canım Y, Kılınç Y, Yılmaz I. Crohn's Disease and Membranous Glomerulonephritis Case Report . MKÜ Tıp Dergisi. 2021;12(44):241-243. https://doi.org/10.17944/mkutfd.819439 


\section{INTRODUCTION}

Inflammatory bowel disease (IBD) is a condition characterized by chronic inflammation of the gastrointestinal tract. The two most common types of IBD are Crohn's disease and Ulcerative colitis. The mechanism underlying IBD is unknown. However, there is convincing evidence that abnormal T cell function mediates in genetically susceptible individuals. Extraintestinal symptoms of IBD are common and can include almost any organ system. The most common involved organs include skin, eyes, joints and hepatobiliary pathways. Renal and urinary involvement has been reported in $4 \%$ to $23 \%$ of IBD patients. IBD urinary involvement manifests as urinary stones, fistula, and ureteral obstruction. Kidney involvement may include secondary amyloidosis, glomerulonephritis (IgA nephropathy, IgM nephropathy, membranous glomerulonephritis, mesangial proliferative glomerulonephritis, anti-glomerular basement membrane disease) and tubulointerstitial nephritis (1-2).

The aim for presenting this case is to report that membranous glomerulonephritis is rare in IBD and to review the literature. In the presence of proteinuria in IBD, glomerulonephritis should be considered.

\section{CASE}

The patient, a 76-year-old male, is presented with peripheral edema. Physical examination showed blood pressure at $130 / 70 \mathrm{mmHg}$, body temperature of $37.3^{\circ} \mathrm{C}$, and peripheral edema. Biochemical profile of the patient was identified as glucose 79 mg/dl (80-1110), blood urea nitrogen 20 mg/dl (728), serum creatinine $1.25 \mathrm{mg} / \mathrm{dl}$ (0.6-1.3), total protein $5,9 \mathrm{~g} /$ dl (6.4-8.3), serum albumin $2.9 \mathrm{~g} / \mathrm{dl}$ (3.5-5.2), potassium 4.7 $\mathrm{mmol} / \mathrm{L}$ (3.5-5.5), serum sodium $140 \mathrm{mmol} / \mathrm{L}$ (135-145), white cell count $7100 \mathrm{~mm}^{3} / \mathrm{uL}, \mathrm{Hb} 12.8 \mathrm{gr} / \mathrm{dL}$, Htc 37.4\%, and platelet count $174000 / \mathrm{mm}^{3}$. Thyroid hormones were detected as normal. Routine urinalysis revealed nephrotic range proteinuria (5.8g/day) and hematuria. Anti-HCV and HbsAg serology were both negative. Autoantibodies, ANCA, ANA, anti-Ds DNA and anti-glomerular basal membrane were negative. Complement C3 and C4 were within normal limits. In kidney biopsy, basal antiglomerular membrane was observed as double contours. Lymphocyte and eosinophil cell inflammation were observed in the tubulointerstitial area. Congo red was negative. Basal membrane $(++)$ and mesangial $(+) \lg$, mesangial $(+)$ IgA, basal membrane (+) IgM, and basal membrane $(+)$ C3 were stained with immunofluorescence. Membranous glomerulonephritis was diagnosed. Conservative treatment was started for the patient. Due to the advanced age of the patient, colonoscopy and gastroscopy were performed for tumor exclusion. Gastroscopy was normal. A colonoscopy detected Crohn's disease. As a result of biopsy, ileum and other segment of colon, mucosal discontinuity, structural crypt distortion, mucosal inflammation, plasma cell infiltration in lamina propria, cryptitis were detected. The pathological examination was in concordance with Crohn's disease. Diarrhea was not among his complaints at the time of admission. When the complaints of the patient were questioned again, he said that he had occasional diarrhea (4-5 times a day) for 2 years. Steroids and 5-aminosalicylates were added to the treatment with the diagnosis of Crohn's disease. Remission was achieved in the patient 3 months after treatment (proteinuria $<300 \mathrm{mg} /$ day).

\section{DISCUSSION}

Kidney damage can be caused by dehydration, malnutrition or as a drug side effect in IBD patients. Glomerulonephritis is one of the renal involvement patterns of IBD. Glomerulonephritis appears to be directly related to bowel disease activity. The etiology of glomerular involvement in IBD is not fully understood. A common pathogenic mechanism or genetic susceptibility may develop as a result of increased mucosal permeability and antigenic exposure of immunocomplexes derived from the intestine. It can also develop because of drug treatment. Renal function recovery is observed after IBD remission (1,3).

Studies exist in literature examining the relationship between glomerulonephritis and IBD. Some of these studies are as follows. In a study of 819 patients who underwent renal biopsy, 28 (3.4\%) were found to have IBD during kidney biopsy. In addition, seven patients were diagnosed with IBD during follow-up. Fourteen of the patients with IBD were classified as Crohn's disease, 14 Ulcerative colitis, and 7 patients not classified as IBD. In this study, the most common glomerulonephritis is IgA nephropathy, with more membranous glomerulonephritis and IgM nephropathy (4). A study conducted by Ambruzs and Larsen detected IBD in 83 of the patients who underwent renal biopsy. Inclined IgA nephropathy was detected among patients with IBD, subsequently interstitial nephritis was detected (5). In the study of Momtaz et al., A total of 896 IBD were taken and 218 of them had renal effects. Renal biopsy was required after an average of $5.6 \pm 7.4$ years after IBD. Nephrotic proteinuria is indicative for the detection of renal biopsy. In renal biopsy, the most common pathology observed amyloidosis. Focal segmental glomerulosclerosis was the second most frequent IgA among glomerulonephritis (6).

The association of membranous glomerulonephritis and Crohn's disease was first detected in a 12-year-old girl (7). Membranous glomerulonephritis was diagnosed in a 37-yearold male patient who was followed up with Crohn's disease for 9 years (8). Membranous glomerulonephritis was diagnosed by renal biopsy in a 38-year-old female patient followed up with Crohn's disease who presented with peripheral edema, proteinuria and hematuria (9). In a 60-year-old male patient followed up with Crohn's disease, who developed proteinuria 
after adalimumab treatment, a diagnosis of membranous glomerulonephritis was established in renal biopsy. Membranous glomerulonephritis has been reported to develop due to the drug (10). Makhlogh et al, diagnosed ulcerative colitis in a 69-year-old female patient who presented with complaints bloody diarrhea, mucoid defecation, and confusion and was followed up for 7 years with the diagnosis of membranous glomerulonephritis (11).

Acute and chronic kidney diseases are common in IBD. In the study conducted by Park et al., A diagnosis of new endstage renal failure was made in $79(0.2 \%)$ patients with IBD and $166(0.1 \%)$ control subjects during an average follow-up period of 4.9 years. Overall, the incidence of end-stage renal failure was significantly higher in the IBD cohort than in the controls. The risk of end-stage renal failure increased in Crohn's patients, but it has not been found to increase in UIcerative colitis. It has been reported in several epidemiological studies that the incidence of kidney failure ranges from $2.0 \%$ to $15.9 \%$ in patients with IBD (12-13).

As a result, renal involvement occurs in IBD patients. Among renal involvement, membranous glomerulonephritis is rarely seen. Our patient showed remission of membranous glomerulonephritis after Crohn's treatment. In this article, we tried to present renal involvement in IBD patients with the literature.

\section{ACKNOWLEDGEMENT}

Peer-Review

Externally Peer Reviewed

Conflict of Interest

The authors declare that they have no conflict of interests regarding content of this article.

Financial Support

The Authors report no financial support regarding content of this article.

Support Resources

No financial support was used by authors during this study. Ethical Declaration

The necessary permission was obtained verbally from the case described in this study, and the Helsinki Declaration criteria were taken into consideration.

\section{REFERENCES}

1. Ambruzs JM, Larsen CP. Renal Manifestations of Inflammatory Bowel Disease. Rheum Dis Clin North Am 2018;44 (4): 699714. https://doi.org/10.1016/j.rdc.2018.06.007

2. Braysh K, Geagea AG, Matar C, Rizzo M, Eid A, Massaad-Massade L, Mallat S. and Jurjus A. Kidney Manifestations of Inflammatory Bowel Diseases. Kidney Manifestations of Inflammatory Bowel Diseases. Open Journal of Gastroenterology, 2018;8(5): 172-191. https://doi.org/10.4236/ojgas.2018.85020
3. Corica D, Romano C. Renal involvement in inflammatory bowel diseases. Journal of Crohn's and Colitis, 2016;10(2):226235. https://doi.org/10.1093/ecco-jcc/jjv138

4. Jussi Pohjonen, Rakel Nurmi, Martti Metso, Pia Oksanen, Heini Huhtala, Ilkka Pörsti, Jukka Mustonen, Katri Kaukinen, Satu Mäkelä Inflammatory bowel disease in patients undergoing renal biopsies Clin Kidney J. 2019; 12(5): 645-651. https://doi. org/10.1093/ckj/sfz004

5. Ambruzs JM, Walker PD, Larsen CP. The histopathologic spectrum of kidney biopsies in patients with inflammatory bowel disease. Clinical Journal of the American Society of Nephrology. 2014;9(2): 265-270. https://doi.org/10.2215/ CJN.04660513

6. Momtaz M, Elaziz A, Fayed A. Patterns of renal involvement in a cohort of patients with inflammatory bowel disease in Egypt. Acta gastroenterol. belg, 2018;81:381-386.

7. O'Loughlin EV, Robson L, Scott B, et al. Membranous glomerulonephritis in a patient with Crohn's disease of the small bowel. J Pediatr Gastroenterol Nutr. 1985;4:135-139.

8. Granja E, Sacristán F, del Río Romero D, Trinidad JC. Association between membranous glomerulonephritis and Crohn's disease. Nefrologia: publicacion oficial de la Sociedad Espanola Nefrologia, 2004;24(4):368-371.

9. Kallel L, Nijaa N, Fatma LB, Rais L, Mustapha NB, Matri S, Filali A. Familial cases of glomerulonephritis complicating Crohn's disease. Journal of Crohn's and Colitis, 2009;3(2):125-127.

10. Gupta A, Pendyala P, Arora P, Sitrin MD. Development of the nephrotic syndrome during treatment of Crohn's disease with adalimumab. Journal of clinical gastroenterology, 2011;45(3):e30-e33.

11. Makhlogh A, and Fakheri H. Tirgar. "Membranous glomerulonephritis associated with ulcerative colitis." 2008: 102-104.

12. Seona Park, Jaeyoung Chun, Kyung-Do Han, Hosim Soh, Kookhwan Choi, Ji Hye Kim, Jooyoung Lee, Changhyun Lee, Jong Pil Im, Joo Sung Kim. Increased end-stage renal disease risk in patients with inflammatory bowel disease: A nationwide population-based study. World J Gastroenterol. 2018; 24(42): 4798-4808. https://doi.org/10.3748/wjg.v24.i42.4798.

13. Lewis B, Mukewar S, Lopez R, Brzezinski A, Hall P, Shen $B$. Frequency and risk factors of renal insufficiency in inflammatory bowel disease inpatients. Inflammatory bowel diseases, 2013;19(9):1846-1851. https://doi.org/10.1097/ MIB.0b013e31828a661e 